\title{
Seyyed Hossein Nasr, Islam in the Modern World: Challenged by the West, Threatened by Fundamentalism, Keeping Faith with Tradition
} (New York: HarperCollins Publishers, 2011). 472 pp. ISBN 978-0-06-190580-3. US\$ 19.49 .

Senad Mrahorovic $\mathrm{PhD}$ candidate, International Institute of Islamic Thought and Civilization (ISTAC), Kuala Lumpur

Islam in the Modern World, is yet another contribution of the Traditionalist perspective by Seyyed Hossein Nasr to an ongoing intellectual discussion concerning Islam and its increasing role in the modern world. As the current state of world affairs portrays, Islam is no longer a religion discussed only in certain academic circles here and there, but rather a subject that is hardly missing from any major headlines of the international media. In the past, the image of Islam, especially in the West, have been distorted as a consequence of the negative and biased representation of it by some Orientalists, Islamicists and missionaries. Today, several other factors have contributed to that distortion due not only to journalistic, secularist and extremist literature on Islam, but also because of various groups from within Islam such as Wahhabism, Salafism, Mahdism and their controversial conception and representation of Islam in European languages. Thus, in the midst of this fallacy and confusion that the Islamic religion has been exposed to, Islam in the Modern World, a book in which Professor Nasr has once again chosen to confer the perennial values and fundamental principles of Islam as it faces difficult challenges brought about by the modern world, comes as an intellectual and religious remedy for those who are truly concerned and interested in this subject. The book is a thoroughly revised and largely updated edition of his famous work Traditional Islam in the Modern World, written over two decades ago. However, as the author has stated, the original structure of this work and its message whose aim was principally religious and intellectual have remained the same, while everything in relation to recent events that have occurred concerning the subject of the book has been reviewed. Hence, this revised edition with newly added materials as well as the inclusion of recent scholarship and much expanded references is a new book.

Beside introductions to both the old and the new editions, and the extensive study of the nature and principles of traditional Islam presented in the "Prologue", the book is divided into five parts. The first part is dedicated to some of the contentious issues discussed among Muslims today. An overview of the state of Islam in the present-day Islamic world, including political, revivalist, reformist and other interpretations of it which to a large extent differ from traditional Islam, is discussed in the first chapter. The second chapter deals with jihād understood as an attempt to attain the equilibrium in one's life, both inwardly and outwardly. Needless to say Nasr's exposition of $j i h \bar{a} d$ and its spiritual significance in the traditional context stands almost entirely in 
contrast to the understanding that this notion has acquired in the past few decades. The next chapter deals with Islamic work ethics and its continuing validity within Islamic society today, despite various challenges of the modern world. Then the study proceeds to the nature of man and woman in Islam, their relationships as well as their respective roles in society envisaged in light of traditional Islamic sources. Finally, the author gives an account of Shi'ism, its historical development and the role it plays today, especially in the Middle East, reflecting also on the relationship between Shi'ism as a minor branch of traditional Islam, and the Sunni world. The spirituality of Islam is another important theme which has been given an excellent treatment in the second part of the book where the author delves into the nature of Islamic spirituality, its challenges and possible prospects in the future. This section then concludes with the treatment and traditional Islamic evaluation of the notion of development in the Islamic world where it has been commonly associated with socioeconomic progress.

Several themes concerning Islamic intellectual tradition are discussed in the third section of the book. The first three chapters are devoted primarily to the nature of traditional Islamic education, Muslim philosophers' views on such an education, and teaching philosophy according to Islamic educational principles. This is followed by the chapter on similarities and differences between Islamic philosophy and science and its modern Western counterparts. In the remaining three chapters, Nasr has beautifully expounded issues related to Islamic art and architecture, highlighting the spiritual significance of Islamic art in the contemporary world, principles of Islamic architecture and urban design in the Islamic world, including major problems in this domain. The Islamic world today and its challenges threatening traditional Islam from both within and without, such as various forms of modernism and fundamentalism were discussed in the fourth section of the book. The final part contains four appendices to which three new chapters have been added. Here in the first two appendices the author has brought to light the nature of traditional Islamic education used in Persian learning institutions, the question of revival of such an education, and the status of philosophy in the Islamic world. The other two are solely devoted to Western academic and traditional scholars of Islam, namely Louis Massignon (d. 1962), Henry Corbin (d. 1978), René Guénon ('Abd al-Wahīi Yaḥyā, d. 1951), Frithjof Schuon ('Īsā Nūr al-Dīn, d. 1998), Titus Burckhardt (Sīdī Ibrāhīm, d. 1984) and Martin Lings (Abū Bakr Sirāj al-Dīn, d. 2005), and their valuable works which have contributed to the better understanding of Islam in the West.

In this intellectual and religious examination of various challenges that Islam is facing today and the authentic presentation and interpretation of central themes pertaining to traditional Islam, in a realm in which one is certainly able to counter and eventually overcome all those challenges, lies the main significance of Islam in the Modern World. 